\title{
Polymorphism of the kappa-casein gene in two Bosnian autochthonous cattle breeds
}

\author{
MUHAMED BRKA ${ }^{1}$, AIDA HODŽIĆ ${ }^{3}$, NORBERT REINSCH², ERVIN ZEČEVIĆ 1 , ADMIR \\ DOKSO ${ }^{1}$, RADICA DJEDOVIĆ ${ }^{3}$, DUNJA RUKAVINA ${ }^{3}$, LEJLA KAPUR ${ }^{4}$, MENSUR VEGARA ${ }^{6}$, \\ MUSTAFA ŠABANOVIĆ ${ }^{7}$ and IVICA RAVIĆ ${ }^{7}$
}

\begin{abstract}
${ }^{1}$ Institute of Animal Breeding, Faculty of Agriculture and Food Sciences, University of Sarajevo, Sarajevo, Bosnia and Herzegovina, ${ }^{2}$ Leibniz Institute for Farm Animal Biology, Dummerstorf, Germany, ${ }^{3}$ Department of Morphology, Veterinary Faculty, University of Sarajevo, Sarajevo, Bosnia and Herzegovina, ${ }^{4}$ Institute for Genetic Engineering and Biotechnology, University of Sarajevo, Sarajevo, Bosnia and Herzegovina, ${ }^{5}$ Institute of Animal Breeding, Faculty of Agriculture, University of Belgrad, Belgrad-Zemun, Serbia, 'Department of International Environment and Development Studies, Norwegian University of Life Science, Aas, Norway, ${ }^{7}$ Veterinary service, Široki Brijeg, Bosnia and Herzegovina
\end{abstract}

\section{Abstract}

Buša is an old endangered autochthonous breed of the western Balkan, especially Bosnia-Herzegovina, Kosovo and Albania. A related breed is Gatačko, derived from Buša $\times$ Tirolean Grey crossbreds. Fifteen purebred Buša cattle and thirteen Gatačko animals were genotyped for polymorphisms at the kappa-casein gene by a Polymerase Chain Reaction-Restriction Fragment Length Polymorphism (PCR-RFLP) essay. The alleles $A, B$ and $C$ were found and the allelic frequencies were $0.46(A), 0.46(B)$ and $0.08(C)$ in Buša cattle and $0.58(A)$ and $0.42(B)$ in Gatačko. Only $A A, A B, B B$ and $B C$ genotypes occurred. Further alleles were not detected and are therefore either absent in both populations or rare. The allele »B« found in this small population will be useful for a sire selection program in the future.

Keywords: kappa-casein polymorphism, endangered breeds, Buša breed, Gatačko breed

\section{Zusammenfassung}

\section{Polymorphismus des Kappa-Kasein-Gens in zwei autochthonen bosnischen Rinderrassen}

Die Buša-Rasse ist eine vom Aussterben bedrohte Rinderrasse des westlichen Balkans, hauptsächlich aus Bosnien und Herzegowina, Kosovo und Albanien. Das Gatačko Rind ist nur in Bosnien-Herzegowina verbreitet und aus einer Kreuzung zwischen Buša und Tiroler Grauvieh hervorgegangen. An einer Stichprobe von insgesamt 28 Tieren, 15 davon Buša und 13 Gatačko, wurden Genotypisierungen des Kappa-Kasein-Genes mit Hilfe einer PCRRFLP-Methode durchgeführt. Die Allele $A, B$ und $C$ hatten Frequenzen von 0,58 (A) und 0,42 (B) bei Bušas und 0,46 (A), 0,46 (B) sowie 0,08 (C) beim Gatačko-Rind. Betrachtet wurden nur die Genotypen $A A, A B, B B$ und $B C$. Weitere Allele wurden nicht gefunden und fehlen daher in beiden Populationen oder sie sind selten. Das B-Allel könnte in beiden kleinen Populationen für die zukünftige Selektion eine Rolle spielen. 
Schlüsselwörter: Kappa-Kasein-Polymorphismus, autochthone Rinderrasse, Buša-Rind, Gatačko-Rind

\section{Introduction}

The Buša breed is an old autochthonous cattle-breed of the western Balkan, namely Bosnia and Herzegovina (BiH), Croatia, Serbia, Kosovo and Albania. While in former days there were thousands of Buša cows in $\mathrm{BiH}$, population size has sharply decreased and nowadays the population counts less than 100 heads. Small size (roughly 102-112 cm), low body weight $(200-250 \mathrm{~kg})$ and an average milk yield of about $2000 \mathrm{~kg}$ per lactation are among the characteristic features of the breed. Due to their low body weight Buša animals are thought to fit especially well in low-input production systems.

The Gatačko breed has been derived from Buša $\times$ Tirolean Greys hundred years ago, and is only found in BiH. Mean body weight $(250-300 \mathrm{~kg})$ and milk yield $(2500 \mathrm{~kg})$ are somewhat higher than in the Buša breed. The current population size is estimated as about 200 heads. For more information on both breeds the reader is referred to ADILOVIĆ et al. (2005); Figure 1 gives a visual impression on the visual impression of Buša and Gatačko animals.

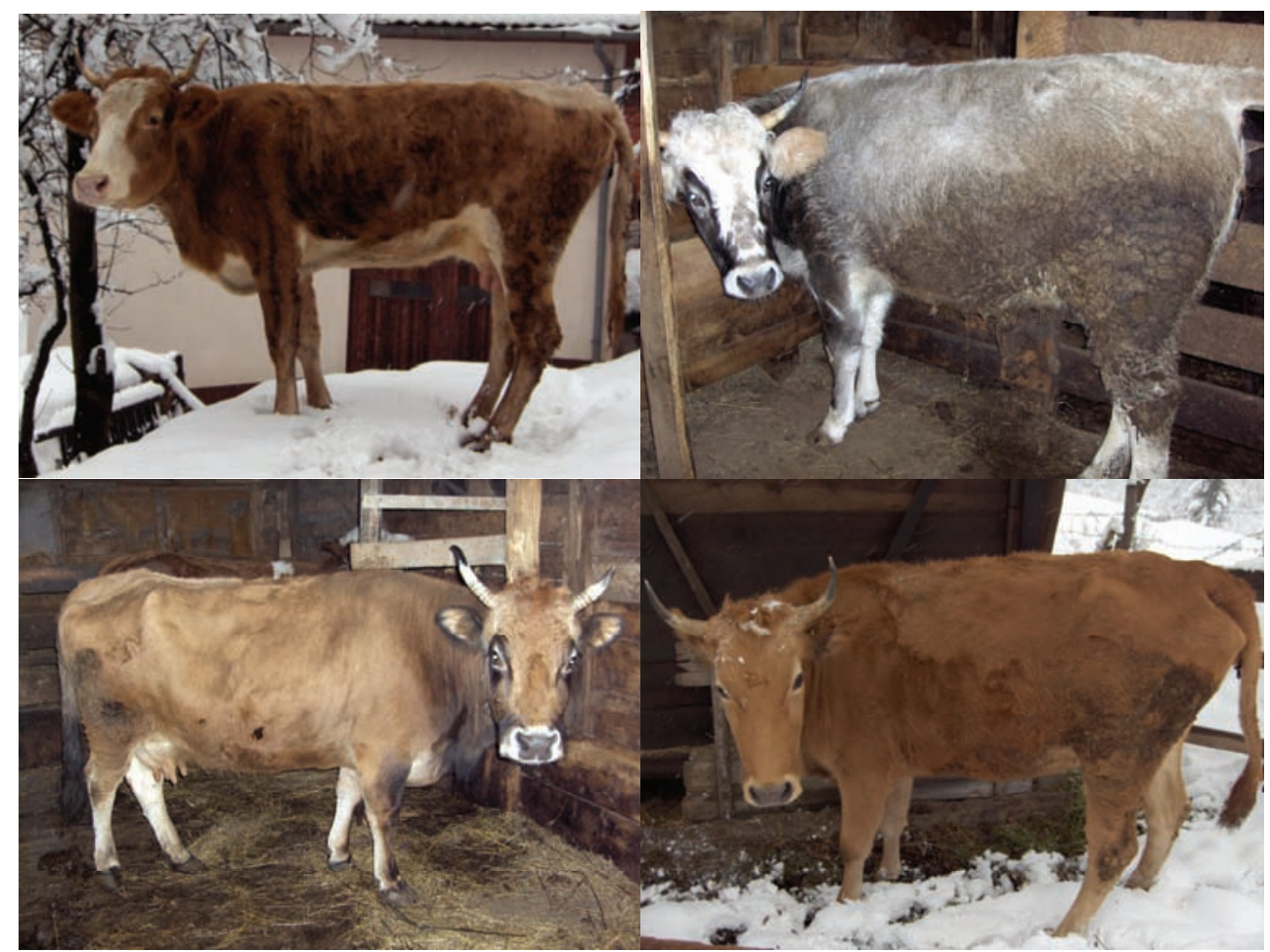

Figure 1

Animals from the autochthonous breeds Buša (above) and Gatačko (below)

Tiere der autochthonen Rassen Buša (oben) und Gatačko (unten) 
The genetic polymorphisms presented by milk proteins are transmitted by simple Mendelian inheritance with no dominance. The casein gene has a role to stabilise the casein micelles and by this it also stabilizes the production characteristics of milk which is particularly relevant in cheese production. So far, six varieties of this gene have been described: A, B, C, E, and, recently, also F and G varieties (KAMINISKY 1996). Many studies show the influence of the genetic variety of kappa-casein on the production characteristics of milk. Milk from animals which have the $B$ variety of the gene shows better lactodinamographic characteristics than milk from animals with the A variety (RAHALI and MÉNARD 1991), E variety (GRAVERT et al. 1991) or C variety (MACHEBOEUF et al. 1990).

MITRA et al. (1998), used for the first time the PCR-RFLP technique with restriction enzymes Hind III, Hinf I and Taq I, this technique made it possible to detect alleles A and B of the kappa-casein gene (CSN3) in Sahiwal cattle (Bos indicus), and in Murrah, Nili-Ravi and Egyptian buffaloes (Bubalus bubalis). A primary PCR product of $379 \mathrm{bp}$ length was amplyfied in a first step. The enzymes Hind III and Taq I produced two fragments of allele B: 156 and $223 \mathrm{bp}$, and 123 and $256 \mathrm{bp}$, respectively. Digestion with Hinf I resulted in three fragments of 132, 156 and $91 \mathrm{bp}$, respectively, for allele A of gene CSN3, and two fragments of 288 and $91 \mathrm{bp}$, respectively, for allele B of gene CSN3, with a frequency of 0.16 in (Bos taurus) cattle. In the Sahiwal breed, 39 animals were identified with genotype CSN3 AA, and the other 18 with genotype CSN3 AB. The genotype BB, however, was not detected among the animals studied. DOGRU and OZDEMIR (2009) observed three genotypes in Brown Swiss with frequencies 19.35, 20.43 and 60.22\% for AA, BB and AB.

The purpose of this work was to investigate for the first time the occurrence and frequency of CSN3-alleles from tissue samples of the BiH autochthonous cattle breeds Buša and Gatačko in order to get insight into an important aspect of both the genetic variability of these severely endangered cattle breeds and the cheese-making properties of their milk.

\section{Material and methods}

In total 28 full-blood samples were collected, 15 of them from BiH autochthonous Buša cattle, which were kept on several farms in middle and north-western Bosnia. Additionally 13 samples of full blood were drawn from BiH Gatačko cattle from a single farm in Gacko. For isolation of genomic DNA standard methods were used (MITRA et al. 1998).

\section{Amplification of the information segment of the kappa-casein gene}

After the previously described analyses, amplification of a fragment of 453 BP by using the standard PCR (Polymerase Chain Reaction) method with the following parameters: F 5'-TGT GCT GAG TAG GTA TCC TAG TTA TGG-3' and R 5'-GCG TTG TCT TCT TTG ATG TCT CCT TAG-3' (BARROSO et al. 1998) was performed. 457I PCR supermix (Cat\# 10572-014, Invitrogen) containing ( $22 \mathrm{mM}$ Tris- $\mathrm{HCl}, 55 \mathrm{mM} \mathrm{KCl}, 1.65 \mathrm{mM} \mathrm{MgCl}, 220 \mu \mathrm{M}$ each of dNTP, 22/L recombinant Taq polymerase stabilisator), per $20 \mathrm{pmol}$ from both primers and $1 / \mathrm{L}$ DNA extract was used in this reaction. Size and yield of PCR product is characterised by the application of agarosis gel-electrophoresis on $1 \%$ agarosis gel (MANIATIS et al. 1982) (Biorad Laboratories, Cat\#162-0126), and the findings were documented as described 
below. The reactions followed the sequence: one cycle at $95^{\circ} \mathrm{C}$ for $30 \mathrm{~s}$ (initial denaturation), and $30 \mathrm{cycles}$ of the sequence: $95^{\circ} \mathrm{C}$ for $60 \mathrm{sec}, 58^{\circ} \mathrm{C}$ for $60 \mathrm{~s}$ and $72^{\circ} \mathrm{C}$ for $45 \mathrm{~s}$ and $7 \mathrm{~min}$ for final elongation at $72^{\circ} \mathrm{C}$. After the reaction was completed, fragments were subjected to electrophoresis in an $(1.5 \%)$ agarose gel, at $90 \mathrm{~V}$ for approximately $1.5 \mathrm{~h}$. Visualization of the bands was done under ultraviolet Trans-illumination and a picture was taken with KODAK Edas system for gel documentation. The size of the amplified product was compared against $50 \mathrm{bp}$ Ladder DNA marker (Fermentas) for qualitative analysis.

\section{Genotyping of kappa-casein gene by PCR-RFLP method}

In the process of genotyping of the amplified gene segment containing the information sites for kappa-casein polymorphism enzymes Hinf I (Invitrogen) - with specific spot - 5'GANTC-3', Hae III (Invitrogen) - 5'-GGCC-3' and HpyCH4 (New England Biolabs) $5^{\prime}$-ACGT-3' have been used. HpyCH4 is isoschizomer for Mae II, an enzyme used in a similar study (BAROSSO et al. 1998). Digestion conditions for all used enzymes were as follows: $1 \mathrm{X}$ of appropriate restricting buffer, $5 \mathrm{U}$ enzyme, $15 \mu \mathrm{L}$ PCR product and $\mathrm{dH}_{2} \mathrm{O} 20 \mu \mathrm{l}$ of the total volume. Three separate reactions are incubated at $37^{\circ} \mathrm{C}$ for the duration of $16 \mathrm{~h}$. Products of restriction analyses are detected on the AGOROZNOM gel dyed by etidiumbromid according to the protocol from MANIATIS et al. (1982). Nomination and interpretation of genotypes were according to BAROSSO et al. (1998).

\section{Results and discussion}

Documented results of agarose-electrophoresis of genomic DNA show that the samples are of sufficiently good quality and concentration of minimally $20-50 \mathrm{ng} / \mathrm{l}$, which is a sufficient quantity for the amplification to be performed on such a matrix (Figure 2 and 3 ).

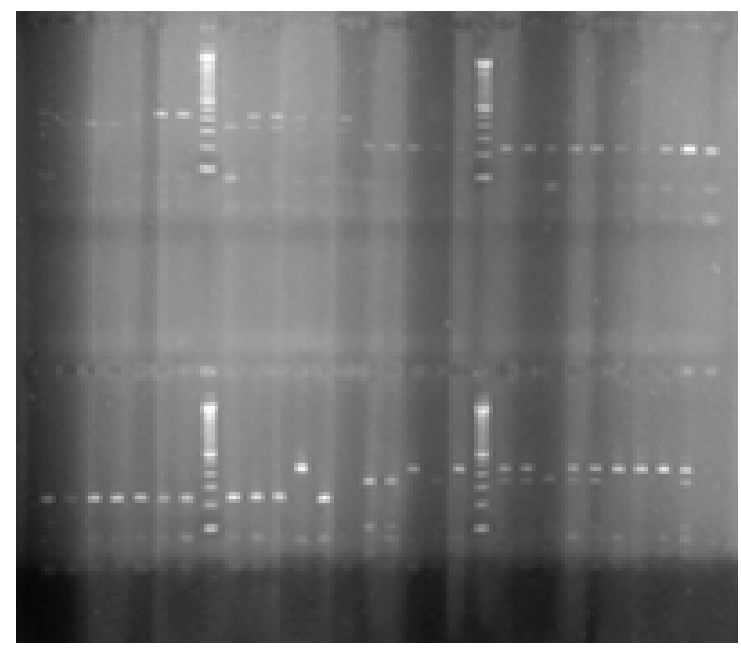

Figure 2

Restriction fragment pattern of PCR-products from the kappa-casein gene

Restriktionsmuster der PCR-Produkte des Kappa-Kasein Gens 


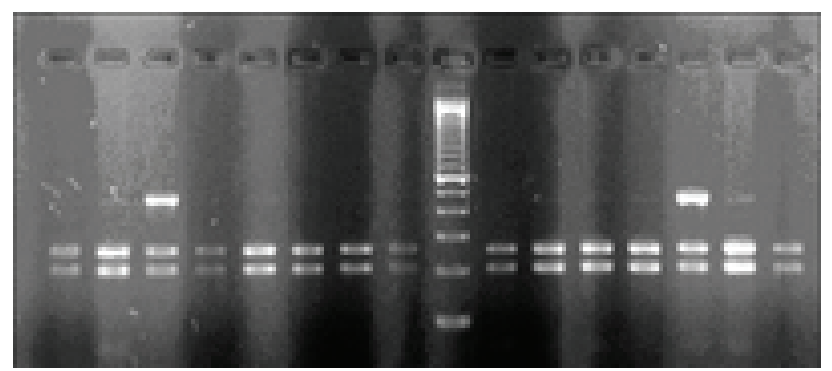

Figure 3

Genotyping results using Tai I (fragments with lengths of 453, 254 and 199 bp are visible)

Ergebnisse der Typisierung mit Tai I (mit sichtbaren Fragmenten der Längen 453, 254 und 199 bp)

Distribution of genotypes in the tested sample has been determined from the research results.

Table

Distribution of genotypes in the sample

Verteilung der Genotypen in der Stichprobe

\begin{tabular}{lccr}
\hline \multirow{2}{*}{ Genotype } & \multicolumn{2}{c}{ Breed, number of animals (\%) } & \multicolumn{2}{c}{ Sum } \\
\hline BA & Buša & Gatačko & $8(29.6)$ \\
AB & $4(28.6)$ & $4(30.8)$ & $12(44.4)$ \\
BB & $5(35.7)$ & $7(53.8)$ & $5(18.6)$ \\
BC & $3(21.4)$ & $2(15.4)$ & $2(7.4)$ \\
\hline
\end{tabular}

The sample analysed by MOODY et al. (1996) contained alleles A, B and C, allele B being the most frequent. The CSN3 allele and genotype frequencies considerably varied in different cattle breeds studied (Table). The frequencies of allele $B$ varied from 0.42 to 0.46 ; and those of genotypes $A B$ and $B B$, from 0.35 to 0.53 and from 0.15 to 0.21 , respectively. The frequency of the B-allele was higher in Buša-cows compared to Gatačko-cattle. In other breeds studied, the frequency of the $B$ allele is high and varied from 0.25 to 0.32 ; and that of the $B B$ genotype, from 0.03 to 0.09 . The BB genotype frequency was extremely high in both breeds and in comparison to other breeds the frequency of the B-allele was considerably high.

Frequencies of both major alleles were not far from 0.5 in both populations. It seems remarkable that both breeds showed considerable genetic variation despite of their small effective population size. The considerably high frequency of the B-allele provides a genetic foundation for good cheese-making properties of the milk from the autochthonous breeds. The frequency of the B-allele may even be further increased by selection, however in doing so the alleles at closely linked milk protein loci should also be regarded (e.g. CZERNIAWSKA-PIĄTKOWSKA) as well as polymorphisms of other genes with possible impact on milk quality (e.g. DYBUS et al. 2004 and kappa-casein effects on other traits (e.g. DYBUS et al. 2005). The test used for the determination of the genetic variants of genes for kappa-casein based on the PCR-RFLP method allows both rapid and efficient examination of the variations of this gene, regardless of the age of animals. In this way it is possible to establish and increase the frequency of desired alleles among animals in studied populations included in the programs of selection and preservation of the autochthonous animal genetic resources in Bosnia and Herzegovina. 


\section{Acknowledgements}

The authors thank the Prof. Türker Savaş for proof reading the manuscript. Special thanks also go to the Norwegian University of Life Sciences for collaboration and support to establish the current new research network and Norwegian Ministry of Foreign Affairs for financial support.

\section{References}

Adilović S, Andrijanić M (2005) Indigenous breeds of domestic animals of Bosnia and Herzegovina. Fakulteta veterinarske medicine u Sarajevu, Sarajevo, Bosnia and Herzegovina

Barroso A, Dunner S, Cañón J (1998) Technical note: Detection of bovine kappa-casein variants A, B, C, and $E$ by means of polymerase chain reaction-single strand conformation polymorphism (PCRSSCP). J Anim Sci 76, 1535-8

Czerniawska-Piątkowska E, Kamieniecki H, Pilarczyk R, Rzewucka E (2004) A comparison of protein polymorphisms in milk produced by two dairy farms in West Pomerania. Arch Tierz 47, 155-63

Dogru U, Ozdemir M (2009) Genotyping of Kappa Casein Locus by PCR-RFLP in Brown Swiss Cattle Breed. J Anim Vet Adv 4, 779-81

Dybus A, Szatkowska I, Czerniawska PE, Grzesiak W, Wójcik J, Rzewucka E, Zych S (2004) PIT1-Hinf I gene polymorphism and its associations with milk production traits in polish Black-and-White cattle. Arch Tierz 47, 557-63

Dybus A, Grzesiak W, Kamieniecki H, Szatkowska I, Sobek Z, Błaszczyk P, Czerniawska-Piątkowska E, Zych S, Muszyńska M (2005) Association of genetic variants of bovine prolactin with milk production traits of Black-and-White and jersey cattle. Arch Tierz 48, 149-56

Gravert H O, Schulte-Coerne H, Ollofs K (1991) The relevance of K-casein for gene-tic differences in cheese making properties. Paper presented at Specialists $\mathrm{mtg}$ of the Int Circle of Dairy Research Leaders on Genetic Polymorphisms of Milk Proteins. 11-12 April 1991, Laboratory of Dairy Science, Swiss Federal Institute of Technology, Zurich, Switzerland

Kaminski S (1996) Bovine kappa-casein (CASK) gene-molecular nature and application dairy cattle breeding. J Appl Genet 37, 179-96

Macheboeuf D, Coulon B. J, DiHour P (1993) Effect of breed, protein genetic variants and feeding on cows' milk coagulation properties. J Dairy Res 60, 43-54

Maniatis T, Fritsch EF, Sambrook J (1982) Molecular Cloning, A Laboratory Manual. Cold Spring Harbor Laboratory, Cold Spring Harbor, New York, USA

Moody D E, Pomp D, Newman S, MacNeil M D (1996) Characterization of DNA polymorphisms in three populations of Hereford cattle and their association whit growth and maternal EPD in line 1 Herefords. J Anim Sci 74, 1784-93

Mitra A, Schlee P, Krause I, Blusch J, Werner T, Balakrishnan CR, Pirchner F (1998) Kappa-casein polymorphisms in Indian dairy cattle and buffalo. A new genetic variant in buffalo. Animal Biotech 9, 81-7

Rahali V, Ménard L (1991) Influence of genetic variants of $\beta$-lactoglobulin and $k$-casein on milk composition and cheese making properties. Lait 71, 275-97

Received 26 June 2009, accepted 10 February 2010.

Corresponding author:

MUHAMED BRKA

email:m.brka@ppf.unsa.ba

Institute of Animal Breeding, Faculty of Agriculture, University of Sarajevo, Zmaja od Bosne 8, 71000

Sarajevo, Bosnia and Hercegovina 